\title{
Arbuscular mycorrhizal fungi are directly and indirectly affected by glyphosate application
}

\author{
Magdalena Druille ${ }^{\mathrm{a}, *}$, Marina Omacini ${ }^{\mathrm{a}}$, Rodolfo A. Golluscio ${ }^{\mathrm{a}}$, Marta N. Cabello ${ }^{\mathrm{b}, \mathrm{c}}$ \\ a IFEVA, Faculty of Agronomy, University of Buenos Aires, CONICET, Av. San Martín 4453, C1417DSE Buenos Aires, Argentina \\ ${ }^{\mathrm{b}}$ Instituto Spegazzini, Faculty of Natural Sciences and Museum, National University of La Plata, Av. 53 N ${ }^{\circ}$ 477, B1900AVJ, La Plata, Argentina \\ ${ }^{\mathrm{c}}$ CICPBA, Argentina
}

\section{A R T I C L E I N F O}

\section{Article history:}

Received 6 March 2013

Received in revised form 8 June 2013

Accepted 30 June 2013

\section{Keywords:}

AMF propagules

Grasslands

Non-target organisms

Root colonization

Spore viability

\begin{abstract}
A B S T R A C T
Glyphosate is a systemic non-selective herbicide, the most widely used in the world. Alongside with its use in agricultural and forestry systems, this herbicide is used in grasslands in late summer with the aim of promoting winter species with the consequent increase in stocking rate. However, its effects on non-target organisms, such as arbuscular mycorrhizal fungi (AMF), are unclear. Arbuscular mycorrhizal fungi (AMF) colonize the root of more than $80 \%$ of terrestrial plants, improving their growth and survival, and therefore playing a key role in ecosystem structure and function. The aim of this work was to investigate the possible pathways through which glyphosate application affects AMF spores viability and root colonization in grassland communities. Our hypothesis is that glyphosate application can damage AMF directly (through contact with spores and external hyphae) or indirectly through the changes it generates on host plants. The experiment had a factorial array with three factors: (1) plant species, at two levels (Paspalum dilatatum and Lotus tenuis), (2) doses of glyphosate, at three levels ( $01 \mathrm{ha}^{-1}, 0.81 \mathrm{ha}^{-1}$ and 31 ha $\left.{ }^{-1}\right)$, and (3) application site, at two levels: soil (direct pathway) and plant foliage (indirect pathway). Spore viability was reduced even under the lowest glyphosate rate, but only when it was applied on the soil. Total root colonization for both species was similarly decreased when glyphosate was applied to plant foliage or on soil, with no difference between 0.8 and $31 \mathrm{ha}^{-1}$. The number of arbuscules was $20 \%$ lower when glyphosate was applied on plant foliage, than when it was applied on the soil. Our findings illustrate that glyphosate application negatively affects AMF functionality in grasslands, due to different causes depending on the herbicide application site. While, under field conditions, the occurrence of direct and/or indirect pathways will depend on the plant cover at the time of glyphosate application, the consequences of this practice on the plant community structure will vary with the mycorrhizal dependence of the species composition regardless of the pathway involved.
\end{abstract}

(C) 2013 Elsevier B.V. All rights reserved.

\section{Introduction}

Glyphosate (N-phosphonomethylglycine) is a systemic nonselective herbicide, the most widely used in the world, to control weeds in horticulture, agriculture, silviculture, and urban landscapes (Woodburn, 2000; Helander et al., 2012), and also in livestock systems (Rodriguez and Jacobo, 2010). Glyphosate competitively inhibits 5-enolpyruvylshikimate-3-phosphate synthase (EPSPS), an enzyme in the shikimate pathway, thereby inhibiting synthesis of aromatic amino acids (phenylalanine, tyrosine, and tryptophan) (Helander et al., 2012). This leads to several metabolic disturbances, including the arrest of protein production and

\footnotetext{
* Corresponding author at: IFEVA-CONICET, Facultad de Agronomía, Universidad de Buenos Aires, Av. San Martín 4453, CPA1417DSE, Buenos Aires, Argentina. Tel.: +54 1145248000

E-mail addresses: druille@ifeva.edu.ar, mdruille@gmail.com (M. Druille).
}

prevention of secondary product formation (Franz et al., 1997). EPSP synthase is not only found in plants but also in bacteria and fungi (Padgette et al., 1995), some of which play key roles in soil nutrient cycling (Roberts et al., 1998; Zablotowicz and Reddy, 2004; Feng et al., 2005).

Risks of glyphosate toxicity to non-target organisms in soils were generally considered as marginal, since glyphosate is prone to rapid microbial degradation and immobilization in soils (Giesy et al., 2000). However, recent studies have also shown that degradation and immobilization are highly variable. Soil sorption and degradation of glyphosate exhibit great variation depending on soil composition and properties (de Jonge et al., 2001; Gimsing et al., 2004, 2007) as well as climate conditions (Borggaard and Gimsing, 2008; Helander et al., 2012). Management practices, such as phosphate fertilization, generate a remobilization of glyphosate residues in soils because P competes for adsorption sites (Bott et al., 2011). In addition, glyphosate can be released into the rhizosphere through root exudations from plants treated with this herbicide 


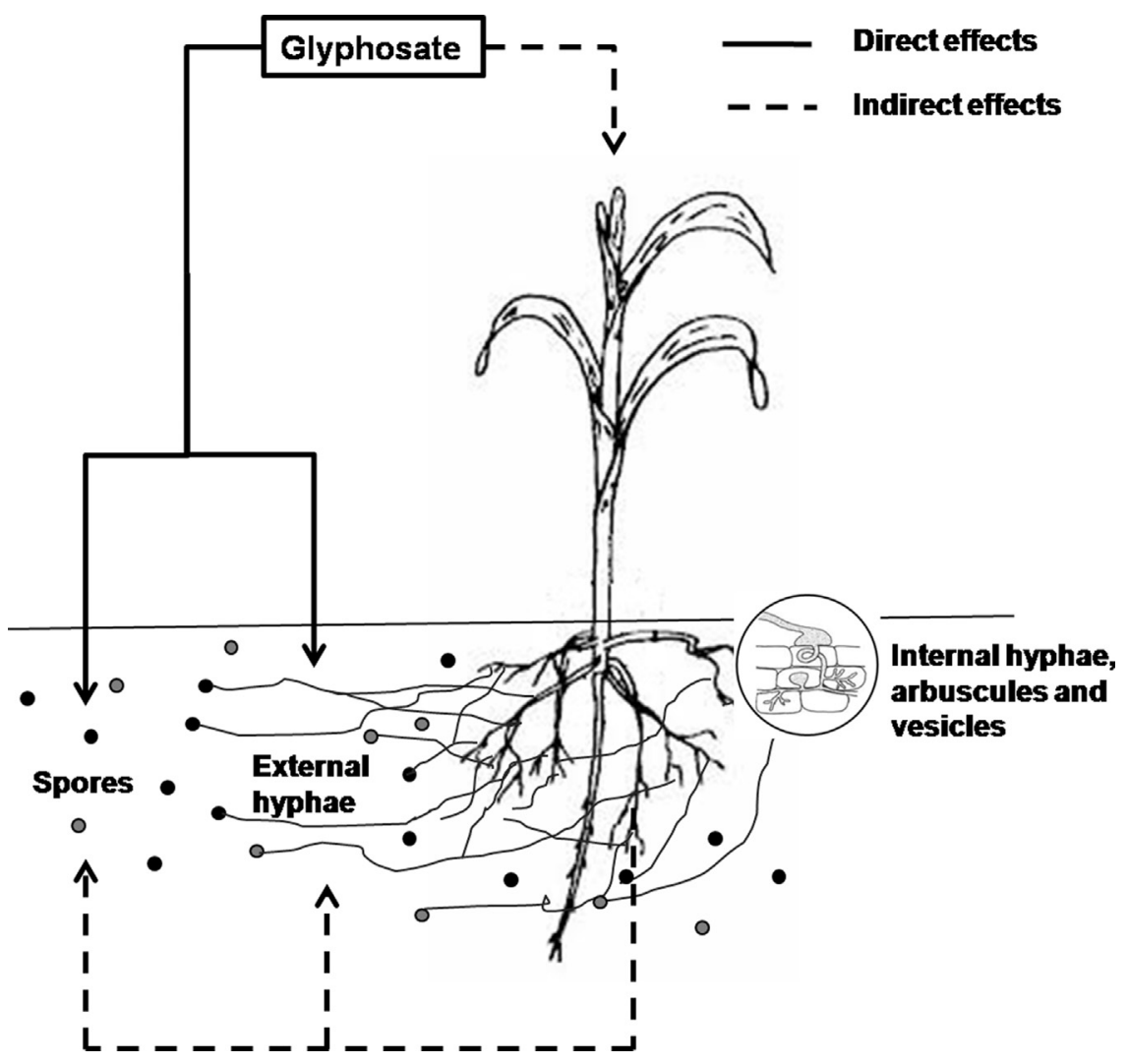

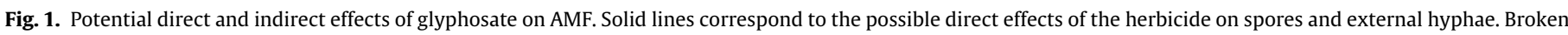

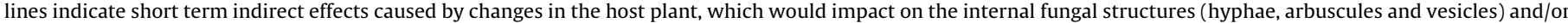
on spores and external hyphae.

(Neumann et al., 2006). Furthermore, aminomethylphosphonic acid (AMPA), the primary degradation product of glyphosate, has a greater environmental persistence and mobility in soil than glyphosate (Battaglin et al., 2005; Kjaer et al., 2005), and it seems to be equally toxic to non-target organisms (Giesy et al., 2000). Hence, the apparently insignificant impacts of glyphosate on aboveground and belowground ecosystem components and processes have recently been challenged (Reddy et al., 2000; Casabé et al., 2007; Tesfamariam et al., 2009; McMullin et al., 2012).

As a result of the key role that plant symbionts play in ecosystems, there is a growing interest in evaluating the effect of glyphosate on arbuscular mycorrhizal fungi (AMF). These fungal symbionts, common to ecosystems worldwide (Brundrett, 2009), are obligate biotrophs horizontally transmitted by three kinds of propagules from the soil: spores, external mycelium and infected root segments (Smith and Read, 2008). AMF can improve growth or performance of a variety of plant species, by improving uptake of phosphorus and other nutrients (Sanders and Fitter, 1992), water relations (Smith and Read, 1997), and protection against pathogens (Newsham et al., 1995). Growth response of colonized plants varies according to the specific identity of colonizing AMF (Bever, 1999), leading to changes in their competitive abilities, hence, affecting plant community structure. As a consequence, AMF may play a key role in the definition of plant diversity, ecosystem variability and productivity (van der Heijden et al., 1998b). Studies have shown contradictory results about the effect of glyphosate on AMF root colonization, ranging from increases to decreases or neutral results (Morandi, 1989; Malty et al., 2006; Ronco et al., 2008). These differences could be due to the different plants and AMF species, different doses of glyphosate, moment and application site (soil or plant foliage) and/or type of substrate used in each case.
A decrease in root colonization and/or abundance of AMF species within all or some of the plant species in the community may be some of the consequences of the negative effect of glyphosate on AMF. Such a reduction could be due to direct or indirect effects of the herbicide (Fig. 1). The former would be associated to the damage to the external hyphae and/or AMF spores caused by glyphosate (Druille et al., 2013), since part of the applied herbicide may end up directly on the soil surface (Helander et al., 2012). Indirect effects, in turn, could occur at two different levels of organization and on different time scales: (1) individual level, through the short term responses that glyphosate causes on the recipient plants and, further on, in their rhizosphere (for example, reducing their ability to provide carbohydrates to the fungus and changing the quantity and quality of exudates) and (2) plant community level through long term changes in species composition and diversity induced by glyphosate. In this paper we considered only the short-term indirect effects.

The aim of this work was to detect the possible pathways through which glyphosate application affects AMF spores viability and root colonization in grassland communities. We tested the hypothesis that glyphosate application reduces AMF both directly, by taking contact with external spores and hyphae, and indirectly, through changes generated on the host plant. To test this hypothesis, we used two plant species, pertaining to different plant functional groups: Lotus tenuis Waldst. \& Kit. ex Willd. (legume) and Paspalum dilatatum Poir ( $C_{4}$ grass). These functional groups are characterized by greater mycorrhizal dependency than nonlegumes dicotyledons and $C_{3}$ grasses (Wilson and Hartnett, 1998). Both species were included in the analysis because the response of mycorrhizal fungi to chemical treatments (Jalali and Domsch, 1975) or other stresses can be influenced by the different host plant species. This essay intends to continue the work carried out 
by Druille et al. (2013), in which a negative effect of glyphosate application on AMF spores was already evidenced.

\section{Materials and methods}

\subsection{Study site, sample collection and growing conditions}

Plants of $P$. dilatatum and $L$. tenuis were collected in summer 2011 from a grazed grassland located near Azul, in the center of the Flooding Pampa region $\left(36^{\circ} 40^{\prime} \mathrm{S}, 59^{\circ} 32^{\prime} \mathrm{W}, 80 \mathrm{~m}\right.$ above sea level). The average annual temperature in the region is $14.6^{\circ} \mathrm{C}$, and annual precipitation is $895 \mathrm{~mm} \mathrm{yr}^{-1}$ (Perelman et al., 2001). The soil was classified as a clay loam typical Natraquoll/US Soil Taxonomy (Mollic Gleyic Solonetz/FAO Soil Taxonomy), with 3.5\% organic matter, $5.6 \mathrm{ppm} \mathrm{P}$ and had a pH of 6.3. Although in this type of grasslands, glyphosate is applied in late summer to promote the growth of winter annuals (Rodriguez and Jacobo, 2010), the study site had no history of herbicide treatment. In mid-February, plants of the same age and size were collected, and placed individually in 11 plastic pots with their associated soil. The soil was handled with caution, in order to maintain its structure (mainly its porosity). Plants were kept in a greenhouse at $25-35^{\circ} \mathrm{C}$ until harvest, and watered to maintain the soil at field capacity, without addition of fertilizers. These were distributed following a completely random design and rotated weekly. Glyphosate application was performed 10 days after transplantation, to ensure plant establishment.

\subsection{Experimental design and herbicide application}

The experiment had a completely randomized design with a factorial array with three factors: (1) plant species, at two levels ( $P$. dilatatum and $L$. tenuis), (2) doses of glyphosate, at three levels $\left(01 \mathrm{ha}^{-1}, 0.81 \mathrm{ha}^{-1}\right.$ and $\left.31 \mathrm{ha}^{-1}\right)$, and (3) application site, at two levels: soil (direct pathway) and plant foliage (indirect pathway). In the first case, glyphosate was applied to the pots once dissolved in $200 \mathrm{~cm}^{3}$ of water, equivalent to a concentration of 3.8 and $14.5 \mathrm{mg} \mathrm{l}^{-1}\left(0.79\right.$ and $\left.3 \mathrm{mg} \mathrm{kg}^{-1}\right)$, for the treatment of $0.8-31 \mathrm{ha}^{-1}$, respectively. The volume of glyphosate solution applied allowed carrying the moisture content of the soils at field capacity (approximately 20\%). This application was made taking care that the solution was not in contact with plant foliage. In the second case, the herbicide was applied to plant foliage using a brush to carefully cover the leaf surface, without coming into contact with soil. Plants for this treatment were watered with $200 \mathrm{~cm}^{3}$ of water, to equalize the water supplied when glyphosate was applied on the soil. Five replicates were performed for each treatment.

\subsection{Measurements}

\subsubsection{AMF spore isolation and viability assessment}

Spores were extracted from a $50 \mathrm{~g}$ sub-sample of air-dried soil for each sample. They were wet-sieved and decanted (Gerdemann and Nicolson, 1963) and the supernatant was centrifuged in a sucrose gradient (Walker et al., 1982). The experimental soil had an average density of 160 spores per $50 \mathrm{~g}$ of dry soil. An's and Hendrix's (1988) procedure was used to determine viable spores, i.e. those developing a red color with the tetrazolium bromide vital stain MTT [3-(4,5-dimethylthiazol-yl)-2,5-diphenyl$2 \mathrm{H}$-tetrazolium bromide]. Spore suspensions were diluted 1:1 with a solution of $0.5 \mathrm{mg} \mathrm{MTT} \mathrm{ml}^{-1}$ and incubated for $40 \mathrm{~h}$.

\subsubsection{AMF root colonization}

Plants were harvested 15 days after glyphosate application. Roots were washed in tap water and cleared with $10 \% \mathrm{KOH}$ for $15 \mathrm{~min}$ at $90^{\circ} \mathrm{C}$, placed in $1 \% \mathrm{HCl}$ for $10 \mathrm{~min}$ and then stained with $0.05 \%$ lactic-glycerol-Trypan Blue for $5 \mathrm{~min}$ at $100^{\circ} \mathrm{C}$ (Phillips and
Hayman, 1970). A total of 20 root fragments (ca. 1-cm long) from each plant were mounted on slides in a polyvinyl alcohol-lactic acid-glycerol solution and examined under microscope at $200 \times$ magnification. Root colonization was assessed with the method proposed by McGonigle et al. (1990); the total colonized roots and the fraction of root length containing arbuscules and vesicles were determined.

\subsubsection{Chlorophyll concentration and green biomass}

To estimate plant vigor, chlorophyll concentration was nondestructively measured using a chlorophyll meter (SPAD-502, Minolta) 15 days after application. Measurements consisted of 10 readings, five on each side of the midrib. Plants were then harvested from the surface of the soil, and green biomass was separated from dead biomass. Dry weight was determined after oven drying for 72 h at $70^{\circ} \mathrm{C}$.

\subsection{Statistical analysis}

Spore viability, chlorophyll content and green biomass data were analyzed using Analysis of Variance (ANOVA). Fungal traits (total root colonization, and percentages of arbuscules and vesicles) were analyzed in a three-way MANOVA. This analysis allows considering fungal traits as a collective measure of AMF response. Pillai's trace was used as the multivariate criterion. When MANOVA showed significant results, we used protected univariate ANOVA analysis to determine which of the response variables was the most affected by treatments (Scheiner, 2001). To obtain homogenous variances, percent data were arcsine square-root transformed $(y=\operatorname{arcsine} \sqrt{ } x)$ before carrying out each analysis. The significance level was set at $\alpha=0.05$. Treatment means were compared using Tukey test when significant $F$ values were found. Although field collected plants were of similar size, green biomass was used as a covariate in the analysis of variance (MANOVA and ANOVA) when evaluating the effect of glyphosate on root colonization.

\section{Results}

\subsection{Spore viability}

A significant interaction was detected between glyphosate rate and application site $\left(F_{[2,47]}=5.17 ; P=0.0093\right)$. A reduction of $40-46 \%$ in AMF spore viability was detected when glyphosate was applied on the soil (direct pathway). This decrease was of similar magnitude in the intermediate rate and field recommended rate, and this effect was independent of the plant species evaluated. When glyphosate was applied on plant foliage, spore viability did not differ from the control treatment (Fig. 2A and B).

\subsection{Root colonization}

A significant effect of plant species, glyphosate rate and application site was found on fungal traits (MANOVA; Table 1), but no effect of the interaction between them was discovered. With regard to root colonization, protected ANOVA shows that there was a significant effect of species (being greater in $L$. tenuis than in $P$. dilatatum) and glyphosate rate (being colonization in plants without glyphosate application higher than the one on plants treated with some of the two doses tested). No significant differences were found between application sites (Table 2 and Fig. $3 A$ and $B$ ).

Percentage of arbuscules showed a response similar to the total root colonization, but in this case a significant effect of application site was found (Table 2). The number of arbuscules was $20 \%$ lower when glyphosate was applied on plant foliage, than when it was applied on the soil (Fig. 3C and D). None of the main factors tested had a significant effect on the percentage of vesicles 

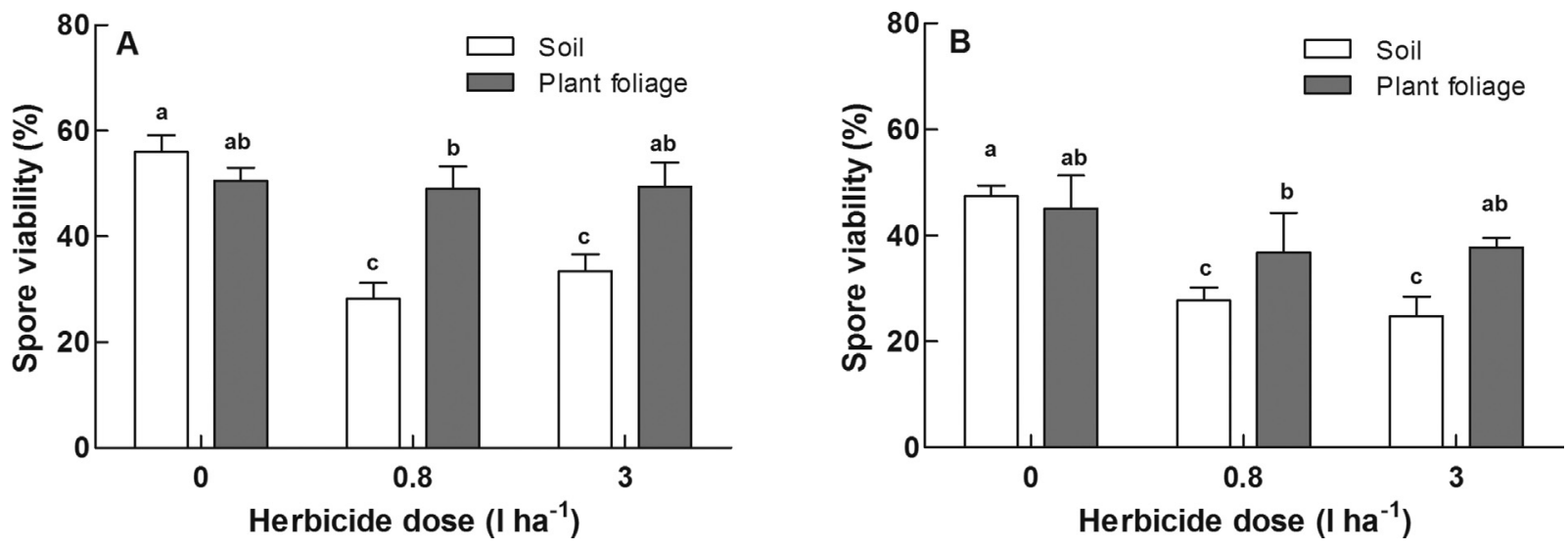

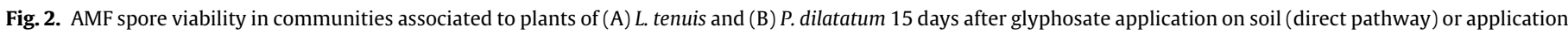
on plant foliage (indirect pathway). Means with the same letter indication are not significantly different at $\alpha=0.05$. Error bars indicate standard error estimates.

Table 1

Results of multivariate analysis of variance (MANOVA) for the effects of plant species, glyphosate rate and application site on fungal traits (total root colonization, percentage of arbuscules and percentage of vesicles).

\begin{tabular}{llll}
\hline Effect & Pillai's trace & d.f. (numerator, denominator) & $F$ \\
\hline Species (S) & $\mathbf{0 . 2 9}$ & $\mathbf{3 , 4 3}$ & $\mathbf{5 . 9 9}^{*}$ \\
Glyphosate rate (G) & $\mathbf{0 . 5 4}$ & $\mathbf{6 , 8 8}$ & $\mathbf{5 . 4 4}^{* *}$ \\
Application site (A) & $\mathbf{0 . 2 3}$ & $\mathbf{3 , 4 3}$ & $\mathbf{4 . 3 0}^{*}$ \\
Green biomass & 0.04 & 3,43 & 0.55 \\
S $\times$ G & 0.25 & 6,88 & 2.07 \\
S $\times$ A & 0.03 & 3,43 & 0.47 \\
G $\times$ A & 0.06 & 6,88 & 0.42 \\
S $\times$ G $\times$ A & 0.22 & 6,88 & 1.86 \\
\hline
\end{tabular}

Pillai's trace was used as the multivariate criterion. Bold denotes significant effects at $P<0.001 ;{ }^{*} P<0.0001$.

(Table 2 and Fig. $3 \mathrm{E}$ and $\mathrm{F}$ ). Both in the MANOVA as in the protected ANOVAs, green biomass introduced as covariate was not significant (Tables 1 and 2), showing that the effects found in root colonization were independent of this variable and solely depended on the application of glyphosate.

\subsection{Chlorophyll content and green biomass}

Regarding chlorophyll content on leaves, a significant interaction was found between glyphosate rate and application site $\left(F_{[2,47]}=28.81 ; P<0.0001\right)$. Glyphosate reduced chlorophyll content when it was applied on plant foliage, but not when it was applied on the soil (Table 3 ). The response described above did not vary between plant species analyzed $\left(F_{[1,47]}=1.66 ; P<0.2035\right)$.

Concerning green biomass, there was no significant effect of plant species $\left(F_{[1,47]}=2.18 ; P=0.1469\right)$. As expected, an interaction was found between glyphosate rate and application site $\left(F_{[2,47]}=26.93 ; P<0.0001\right)$. There was a decrease in green biomass when glyphosate was applied on plant foliage, and this decrease was significantly greater when the highest dose was applied in relation to the intermediate rate. When the glyphosate was applied on the soil, green biomass values were similar to the control treatment.

\section{Discussion}

To the best of our knowledge, this study is the first to experimentally evaluate the possible pathways through which glyphosate can damage AMF. As hypothesized, these fungi were affected directly and indirectly by glyphosate application. The importance of each pathway depended on the fungal structure evaluated. Due to the different degree of mycorrhizal dependency that different plant species present (Habte and Manjunath, 1991), our results suggest that glyphosate regulation of AMF structures into the soil and arbuscule formation for nutrient acquisition from host may lead to floristic changes in the grassland plant community (Gange et al., 1993; van der Heijden et al., 1998a; Bever, 1999; Gange et al., 1999). At the same time, glyphosate application causes changes in species composition in the short-medium term (Rodriguez and Jacobo, 2010), which could affect the diversity of AMF considering the dependency between both communities (Bever, 1999).

Spore viability was reduced only when glyphosate was applied on the soil (direct pathway), being this reduction similar between the intermediate and high doses. The magnitude of this direct effect was lower than that reported by Druille et al. (2013), and this could be due to the degree of disturbance caused on the soil. In the previous experiment conducted by Druille et al. (2013) soil was sieved $(2 \mathrm{~mm})$ and homogenized, whereas in this experiment, soil maintained its structure and host plant was present. Malty et al. (2006) found that glyphosate inhibits germination and growth of AMF spore in culture media, but not when it is applied to soil before soybean sowing. This direct effect on spores may depend on the AMF species evaluated. Herbicide inhibition on germination and growth of AMF spore germ tubes showed a decreasing tendency

Table 2

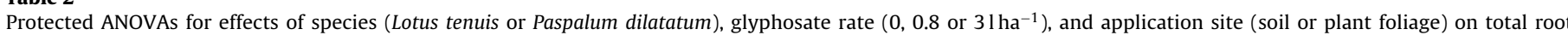
colonization, arbuscules and vesicles.

\begin{tabular}{|c|c|c|c|c|c|c|c|}
\hline & \multicolumn{3}{|c|}{ Root colonization } & \multicolumn{2}{|c|}{ Arbuscules } & \multicolumn{2}{|c|}{ Vesicles } \\
\hline & d.f. & $F$ & $P$ & $F$ & $P$ & $F$ & $P$ \\
\hline Species & 1,53 & 14.38 & 0.0004 & 9.90 & 0.0027 & 0.04 & 0.8393 \\
\hline Herbicide rate & 2,53 & 17.41 & $<0.0001$ & 12.80 & $<0.0001$ & 0.75 & 0.4774 \\
\hline Application site & 1,53 & 0.90 & 0.3461 & 17.91 & $<0.0001$ & 0.20 & 0.6544 \\
\hline Green biomass & 1,53 & 0.54 & 0.4644 & 2.13 & 0.1500 & 2.74 & 0.1040 \\
\hline
\end{tabular}

Bold denotes significant effects $(\alpha=0.05)$. 
Lotus tenuis
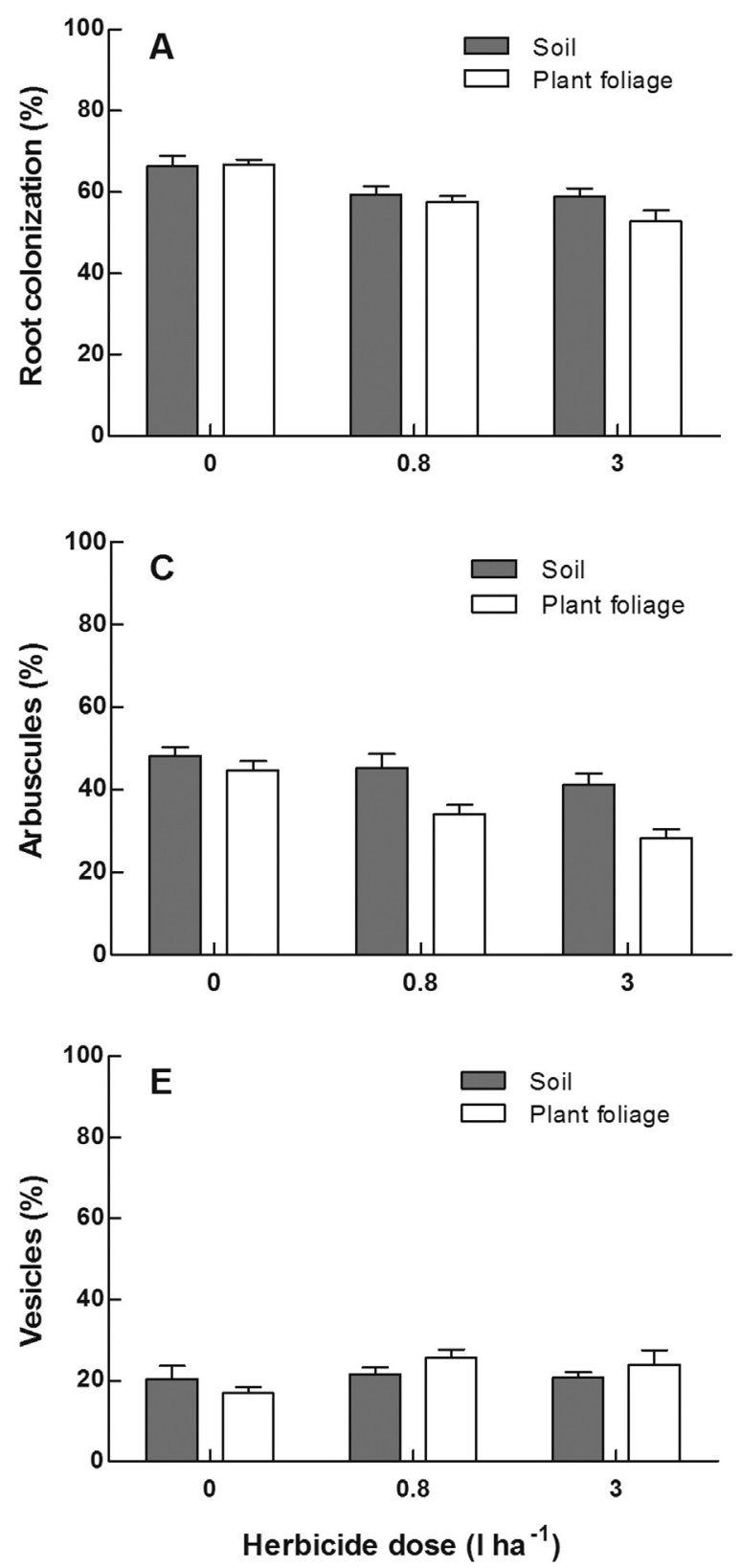

Paspalum dilatatum
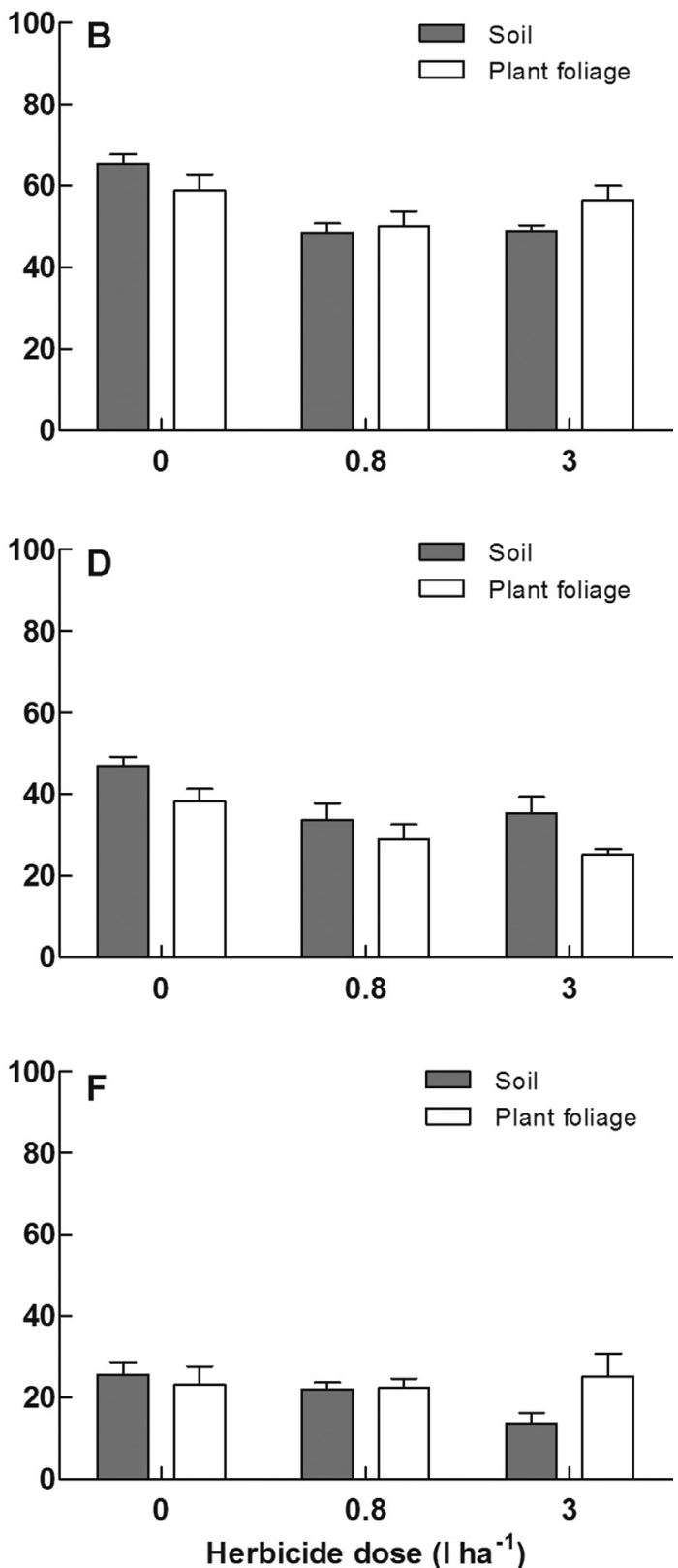

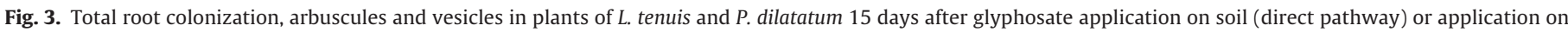
plant foliage (indirect pathway). Error bars indicate standard error estimates.

Table 3

Chlorophyll content of plants of $L$. tenuis and P. dilatatum, 15 days after glyphosate application.

\begin{tabular}{|c|c|c|c|c|c|c|c|}
\hline & \multirow{4}{*}{ Species } & \multicolumn{6}{|c|}{ Glyphosate rate $\left(\mathrm{lha}^{-1}\right)$} \\
\hline & & \multicolumn{2}{|l|}{0} & \multicolumn{2}{|l|}{0.8} & \multicolumn{2}{|l|}{3} \\
\hline & & \multicolumn{6}{|c|}{ Application site } \\
\hline & & Soil & Plant foliage & Soil & Plant foliage & Soil & Plant foliage \\
\hline $\begin{array}{l}\text { Chlorophyll content } \\
\text { (SPAD units) }\end{array}$ & $\begin{array}{l}\text { L. tenuis } \\
\text { P. dilatatum }\end{array}$ & $\begin{array}{l}40.2 \pm 2.5^{\mathrm{a}} \\
37.9 \pm 2.4^{\mathrm{a}}\end{array}$ & $\begin{array}{l}34.3 \pm 1.4^{\mathrm{a}} \\
34.9 \pm 1.0^{\mathrm{a}}\end{array}$ & $\begin{array}{l}36.3 \pm 4.1^{\mathrm{a}} \\
36.6 \pm 1.2^{\mathrm{a}}\end{array}$ & $\begin{array}{l}19.5 \pm 0.7^{\mathrm{b}} \\
13.8 \pm 1.8^{\mathrm{b}}\end{array}$ & $\begin{array}{l}34.1 \pm 0.8^{\mathrm{a}} \\
36.3 \pm 1.1^{\mathrm{a}}\end{array}$ & $\begin{array}{l}12.8 \pm 0.8^{\mathrm{b}} \\
11.4 \pm 3.1^{\mathrm{b}}\end{array}$ \\
\hline
\end{tabular}

Mean values of five replicates \pm standard errors are shown. In each row, means followed by different letters are significantly different $(P<0.05)$ by Tukey tests.

from Glomus etunicatum to Scutellospora heterogama and Gigaspora margarita (Malty et al., 2006), and being null in Glomus mosseae (Giovannetti et al., 2006). The absence of indirect effects indicates that although glyphosate can be exuded by roots of plants treated with this herbicide (Neumann et al., 2006), the quantity in the rhizosphere was not enough to affect spores viability.

Total root colonization was reduced in the same magnitude when glyphosate was applied at 0.8 or $31 \mathrm{ha}^{-1}$, demonstrating high 
sensitivity of these microorganisms to glyphosate. This implies that the damage caused by this herbicide may not only be perceived on the area to be treated, but in the surrounding areas through wind driven drift of the herbicide spray. Strong winds and poor application procedures may result in total spray drift as high as 37\% (Nordby and Skuterud, 1974). There were no significant differences in the magnitude of the reduction of root colonization when glyphosate was applied on plant foliage or on soil. However, the causes of this reduction should be different depending on the application site of the herbicide.

When glyphosate was applied on soil (direct pathway), the reduction in root colonization may have been due to the damage that glyphosate (the active ingredient, any of the adjuvants and/or some of its degradation product, as AMPA) could have caused in external hyphae and/or spores. Ronco et al. (2008) found a reduction in root colonization, arbuscules and vesicles in pepper plants sown in soil previously treated with glyphosate. This would indicate that herbicide application reduced the amount of previously added propagules to the substrate (spores, mycorrhizal root fragments, and mycelium of G. mosseae). We are aware that there may be other explanations for these results. As mentioned above, glyphosate can damage other microorganisms present in the soil, which, in turn, can modify the functionality of the AMF (Garbaye, 1994).

The fall in root colonization when glyphosate was applied to plant foliage (indirect pathway) could be due to carbon stress produced in the host plant. As shown in Table 3, glyphosate application reduced chlorophyll content in leaves when it was applied on plant foliage, and this would impact on photosynthetic rate. This reduction together with diminished green foliar area in plants treated with this herbicide could reduce carbon flow to the roots, thus affecting root colonization (Bethlenfalvay and Dakessian, 1984; Hampp and Schaeffer, 1999). Indirect effect on root colonization found in this study does not coincide with some previous research. In part, the null effect reported elsewhere may be due to the use of genetically modified plants (mainly soybean) that resist glyphosate application (Mujica et al., 1999; Powell et al., 2009; Savin et al., 2009). Therefore, plants do not suffer carbon stress because photosynthetic rates and leaf area remain unchanged.

Arbuscules were also reduced through glyphosate application, but in this case there was an effect of application site. The reduction in percentage of arbuscules was higher when glyphosate was applied on plant foliage (indirect pathway) that when it was applied on soil (direct pathway). This indicates a greater sensitivity of this structure to changes in the supply of carbohydrates by the plant, relative to the direct effect on spores and external hyphae and their capacity to generate arbuscules within the root in soil treated with this herbicide. In both cases, the reduction in the percentage of arbuscules implies that the functionality of the symbiosis was affected, given these structures are the main site for host-fungus nutrient exchange (Smith and Gianinazzi-Pearson, 1988).

Therefore, the results presented in this paper support the conclusion that glyphosate directly and indirectly damages AMF, which may impact on the interaction between these symbionts and their host plants in grasslands. Under field conditions, direct and indirect size effects will depend on the plant cover at the time of glyphosate application, and this will impact differently on their life cycle, since the importance of each pathway depended on the fungal structure evaluated. In grasslands where the application of glyphosate is made with the aim to promote winter species (Rodriguez and Jacobo, 2010), plant cover will depend on the density of plants per square meter (which can vary depending on the degree of grassland deterioration), and the days elapsed since the last grazing.

Further studies should be performed in order to evaluate this effect in other soil types which differ in texture (and therefore in herbicide adsorption capacity and microbial activity) and in different host plants with different mycorrhizal dependency and glyphosate sensitivity. Field experiments are also required to confirm these potential effects of AMF on plant community and the possible long-term effects of these changes on AMF community, taking into account the dependency between them (Bever, 1999). Moreover, it will be necessary to elucidate the mechanisms involved, since negative effects could be due to glyphosate itself, its degradation products, any of the adjuvants, or changes in soil environment. Given the strength of their effect, AMF should be incorporated into management practices and research priorities.

\section{Acknowledgements}

This research was supported by grants from BID-PICT 00463 , CONICET and CICPBA. We thank Agustín Grimoldi for his advice on the experimental design, and Pedro Sosa, Luis Ignacio Perez, Carla Di Bella and Mercedes Vassallo for their technical assistance. We also thank three anonymous referees for constructive comments and suggestions that substantially improved the manuscript.

\section{References}

An, Z.Q., Hendrix, J.W., 1988. Determining viability of endogonaceous spores with a vital stain. Mycologia 80, 259-261.

Battaglin, W.A., Kolpin, D.W., Scribner, E.A., Kuivila, K.M., Sandstrom, M.W., 2005 Glyphosate, other herbicides, and transformation products in Midwestwern streams. J. Am. Water Resour. Assoc. 41, 323-332.

Bethlenfalvay, G.J., Dakessian, S., 1984. Grazing effects on mycorrhizal colonization and floristic composition of the vegetation on a semiarid range in northern Nevada. J. Range Manage. 37, 312-316.

Bever, J.D., 1999. Dynamics within mutualism and the maintenance of diversity: inference from a model of interguild frequency dependence. Ecol. Lett. 2, 52-61.

Borggaard, O.K., Gimsing, A.L., 2008. Fate of glyphosate in soil and the possibility of leaching to ground and surface waters: a review. Pest Manag. Sci. 64, 441-456.

Bott, S., Tesfamariam, T., Kania, A., Eman, B., Aslan, N., Römheld, V., Neumann, G. 2011. Phytotoxicity of glyphosate soil residues re-mobilised by phosphate fertilisation. Plant Soil 342, 249-263.

Brundrett, M.C., 2009. Mycorrhizas in natural ecosystems. Adv. Ecol. Res. 21, $171-313$.

Casabé, N., Piola, L., Fuchs, J., Oneto, M., Pamparato, L., Basack, S., Giménez, R., Massaro, R., Papa, J., Kesten, E., 2007. Ecotoxicological assessment of the effects of glyphosate and chlorpyrifos in an Argentine soya field. J. Soil. Sediment. 7 $232-239$.

de Jonge, H., de Jonge, L.W., Jacobsen, O.H., Yamaguchi, T., Moldrup, P., 2001. Glyphosate sorption in soils of different $\mathrm{pH}$ and phosphorus content. Soil Sci. 166, 230-238

Druille, M., Cabello, M.N., Omacini, M., Golluscio, R.A., 2013. Glyphosate reduces spore viability and root colonization of arbuscular mycorrhizal fungi. Appl. Soil Ecol. 64, 99-103.

Feng, P.C.C., Baley, G.J., Clinton, W.P., Bunkers, G.J., Alibhai, M.F., Paulitz, T.C., Kidwell, K.K., 2005. Glyphosate inhibits rust diseases in glyphosate-resistant wheat and soybean. Proc. Natl Acad. Sci. U.S.A. 102, 17290-17295.

Franz, J.E., Mao, M.K., Sikorski, J.A., 1997. Glyphosate: A Unique Global Herbicide, American Chemical Society Monograph. American Chemical Society, Washington, DC.

Gange, A.C., Brown, V.K., Sinclair, G.S., 1993. Vesicular-arbuscular mycorrhizal Fungi: a determinant of plant community structure in early succession. Funct. Ecol. 7, 616-622.

Gange, A.C., Lindsay, D.E., Ellis, L.S., 1999. Can arbuscular mycorrhizal fungi be used to control the undesirable grass Poa annua on golf courses? J. Appl. Ecol. 36, 909-919.

Garbaye, J., 1994. Tansley Review No. 76. Helper bacteria: a new dimension to the mycorrhizal symbiosis. New Phytol. 128, 197-210.

Gerdemann, J.W., Nicolson, T.H., 1963. Spores of mycorrhizal Endogone species extracted from soil by wet sieving and decanting. Trans. Br. Mycol. Soc. 46 $235-244$

Giesy, J.P., Dobson, S., Solomon, K.R., 2000. Ecotoxicological risk assessment for Roundup ${ }^{\circledR}$ herbicide. Rev. Environ. Contam. Toxicol. 167, 35-120.

Gimsing, A.L., Borggaard, O.K., Jacobsen, O.S., Aamand, J., S.Ãrensen, J., 2004. Chemical and microbiological soil characteristics controlling glyphosate mineralisation in Danish surface soils. Appl. Soil Ecol. 27, 233-242.

Gimsing, A.L., Szilas, C., Borggaard, O.K., 2007. Sorption of glyphosate and phosphate by variable-charge tropical soils from Tanzania. Geoderma 138, 127-132.

Giovannetti, M., Turrini, A., Strani, P., Sbrana, C., Avio, L., Pietrangeli, B., 2006. Mycorrhizal fungi in ecotoxicological studies: soil impact of fungicides, insecticides and herbicides. Prevent. Today 2, 47-62

Habte, M., Manjunath, A., 1991. Categories of vesicular-arbuscular mycorrhizal dependency of host species. Mycorrhiza 1, 3-12. 
Hampp, R., Schaeffer, C., 1999. Mycorrhiza - carbohydrate and energy metabolism. In: Varma, A.H.B. (Ed.), Mycorrhiza. Structure, Function, Molecular Biology and Biotechnology. Springer-Verlag, Berlin, Heideberg, pp. 273-303.

Helander, M., Saloniemi, I., Saikkonen, K., 2012. Glyphosate in northern ecosystems. Trends Plant Sci. 17, 569-574.

Jalali, B., Domsch, K., 1975. Effect of systemic fungi-toxicants on the development of endotrophic mycorrhiza. In: Sanders, F.E.M.B., Tinker, P.B. (Eds.), Endomycorrhizas. Academic press, New York, pp. 619-626.

Kjaer, G.A., Olsen, P., Ullum, M., Grant, R., 2005. Leaching of glyphosate and aminophosphonic acid from Danish agricultural field sites. J. Environ. Qual. 34, 608-620.

Malty, J.d.S., Siqueira, J.O., Moreira, F.M.d.S., 2006. Efeitos do glifosato sobre microrganismos simbiotróficos de soja, em meio de cultura e casa de vegetação. Pesquisa Agropecuaria Brasileira 41, 285-291.

McGonigle, T.P., Miller, M.H., Evans, D.G., Fairchild, G.L., Swan, J.A., 1990. A new method which gives an objective measure of colonization of roots by vesicular-arbuscular mycorrhizal fungi. New Phytol. 115, 495-501.

McMullin, R.T., Wayne Bell, F., Newmaster, S.G., 2012. The effects of triclopyr and glyphosate on lichens. Forest Ecol. Manag. 264, 90-97.

Morandi, D., 1989. Effect of xenobiotics on endomycorrhizal infection and isoflavonoid accumulation in soybean roots. Plant Physiol. Biochem. 27, 697-701.

Mujica, M.T., Fracchia, S., Ocampo, J.A., Godeas, A., 1999. Influence of the herbicides chlorsulfuron and glyphosate on mycorrhizal soybean intercropped with the weeds Brassica campestris or Sorghum halepensis. Symbiosis 27, 73-81.

Neumann, G., Kohls, S., Landsberg, E., Stock-Oliveira Souza, K., Yamada, T., Römheld, V., 2006. Relevance of glyphosate transfer to non-target plants via the rhizosphere. J. Plant Dis. Protect. 20, 963-969.

Newsham, K.K., Fitter, A.H., Watkinson, A.R., 1995. Arbuscular mycorrhiza protect an annual grass from root pathogenic fungi in the field. J. Ecol. 83, 991-1000.

Nordby, A.L.F., Skuterud, R., 1974. The effects of boom height, working pressure and wind speed on spray drift. Weed Res. 14, 385-395.

Padgette, S.R., Kolacz, K.H., Delannay, X., Re, D.B., LaVallee, B.J., Tinius, C.N., Rhodes, W.K., 1995. Development, identification, and characterization of a glyphosatetolerant soybean line. Crop Sci. 35, 1451-1461.

Perelman, S.B., León, R.J.C., Oesterheld, M., 2001. Cross-scale vegetation patterns of Flooding Pampa grasslands. J. Ecol. 89, 562-577.

Phillips, J.M., Hayman, D.S., 1970. Improved procedures for clearing roots and staining parasitic and vesicular-arbuscular mycorrhizal fungi for rapid assessment of infection. Trans. Br. Mycol. Soc. 55, 158-161.

Powell, J.R., Campbell, R.G., Dunfield, K.E., Gulden, R.H., Hart, M.M., Levy-Booth, D.J., Klironomos, J.N., Pauls, K.P., Swanton, C.J., Trevors, J.T., Antunes, P.M., 2009. Effect of glyphosate on the tripartite symbiosis formed by Glomus intraradices, Bradyrhizobium japonicum, and genetically modified soybean. Appl. Soil Ecol. 41, $128-136$.

Reddy, K.N., Hoagland, R.E., Zablotowicz, R.M., 2000. Effect of glyphosate on growth, chlorophyll, and nodulation in glyphosate-resistant and susceptible soybean (Glycine max) varieties. J. New Seeds 2, 37-52.
Roberts, F., Roberts, C.W., Johnson, J.J., Kyle, D.E., Krell, T., Coggins, J.R., Coombs, G.H., Milhous, W.K., Tzipori, S., Ferguson, D.J.P., Chakrabarti, D., McLeod, R., 1998. Evidence for the shikimate pathway in apicomplexan parasites. Nature 393, 801-805.

Rodriguez, A.M., Jacobo, E.J., 2010. Glyphosate effects on floristic composition and species diversity in the Flooding Pampa grassland (Argentina). Agriculture. Ecosyst. Environ. 138, 222-231.

Ronco, M.G., Ruscitti, M.F., Arango, M.C., Beltrano, J., 2008. Glyphosate and mycorrhization induce changes in plant growth and in root morphology and architecture in pepper plants (Capsicum annuum L.). J. Hortic. Sci. Biotechnol. 83, 497-505.

Sanders, I.R., Fitter, A.H., 1992. Evidence for differential responses between hostfungus combinations of vesicular-arbuscular mycorrhizas from a grassland. Mycol. Res. 96, 415-419.

Savin, M., Purcell, L., Daigh, A., Manfredini, A., 2009. Response of mycorrhizal infection to glyphosate applications and P fertilization in glyphosate-tolerant soybean, maize, and cotton. J. Plant Nutr. 32, 1702-1717.

Scheiner, S., 2001. MANOVA: multiple response variables and multispecies interactions. In: Scheiner, S.M., Gurevitch, J. (Eds.), MANOVA: Multiple Response Variables and Multispecies Interactions. Oxford University Press, New York, pp. 99-115.

Smith, S.E., Gianinazzi-Pearson, V., 1988. Physiological interactions between symbionts in vesicular-arbuscular mycorrhizal plants. Annu. Rev. Plant Physiol. Plant Mol. Biol. 39, 221-244.

Smith, S.E., Read, D.J., 1997. Mycorrhizal Symbiosis, 2nd ed. Academic Press, San Diego, CA.

Smith, S.E., Read, D.J., 2008. Mycorrhizal Symbiosis, 3rd ed. Academic Press, London.

Tesfamariam, T., Bott, S., Cakmak, I., Römheld, V., Neumann, G., 2009. Glyphosate in the rhizosphere - role of waiting times and different glyphosate binding forms in soils for phytotoxicity to non-target plants. Eur. J. Agron. 31, 126-132.

van der Heijden, M.G.A., Boller, T., Wiemken, A., Sanders, I.R., 1998a. Different arbuscular mycorrhizal fungal species are potential determinants of plant community structure. Ecology 79, 2082-2091.

van der Heijden, M.G.A., Klironomos, J.N., Ursic, M., Moutoglis, P., Streitwolf-Engel, R., Boller, T., Wiemken, A., Sanders, I.R., 1998b. Mycorrhizal fungal diversity determines plant biodiversity, ecosystem variability and productivity. Nature 396, 69-72.

Walker, C., Mize, C.W., McNabb Jr., H.S., 1982. Populations of endogonaceous fungi at two locations in central Iowa. Can. J. Bot. 60, 2518-2529.

Wilson, G.W.T., Hartnett, D.C., 1998. Interspecific variation in plant responses to mycorrhizal colonization in tallgrass prairie. Am. J. Bot. 85, $1732-1738$.

Woodburn, A.T., 2000. Glyphosate: production, pricing and use worldwide. Pest Manag. Sci. 56, 309-312.

Zablotowicz, R.M., Reddy, K.N., 2004. Impact of glyphosate on the Bradyrhizobium japonicum symbiosis with glyphosate-resistant transgenic soybean. J. Environ. Qual. 33, 825-831. 